\title{
Determinants of the Sales Market of Products of Meat Processing Complex in the Innovation and Investment System of Regional Polarized
}

\author{
Svitlana A. Nesterenko*, Iryna V. Ahieieva, Nonna V. Surzhenko, Olena Yu. Shevchuk, \\ Anhelina V. Yarchuk
}

Department of Management, Dmytro Motornyi Tavria State Agrotechnological University, 72310, Melitopol, Ukraine

Received February 1, 2021; Revised May 13, 2021; Accepted June 4, 2021

(a): [1] Svitlana A. Nesterenko, Iryna V. Ahieieva, Nonna V. Surzhenko, Olena Yu. Shevchuk, Anhelina V. Yarchuk, "Determinants of the Sales Market of Products of Meat Processing Complex in the Innovation and Investment System of Regional Polarized," Food Science and Technology, Vol. 9, No. 2, pp. 31-44, 2021. DOI: 10.13189/fst.2021.090202.

(b): Svitlana A. Nesterenko, Iryna V. Ahieieva, Nonna V. Surzhenko, Olena Yu. Shevchuk, Anhelina V. Yarchuk (2021). Determinants of the Sales Market of Products of Meat Processing Complex in the Innovation and Investment System of Regional Polarized. Food Science and Technology, 9(2), 31-44. DOI: 10.13189/fst.2021.090202.

Copyright $\bigcirc 2021$ by authors, all rights reserved. Authors agree that this article remains permanently open access under the terms of the Creative Commons Attribution License 4.0 International License

\begin{abstract}
The article considers the determinants of the sales market development of meat processing complex products that implement the parameters of innovation and investment capacity of local subjects in the innovation and investment system of the regional polarized space. The purpose of this study was to characterize Ukrainian sales market development of meat processing complex products. A comprehensive methodological approach to the systematic diagnosis of the time interval for the sale of meat processing complex products of the region according to the level of spatial polarization of innovation and investment capacity of the subject has been developed. The determinants of the development of the sales market for meat products have been identified. The forecast spatio-temporal interval of sales of meat processing complex products according to the level of innovation and investment capacity of the subjects in the polarized innovation and investment system of the region is interpreted. The analysis of production and marketing activities of agro-clusters of the meat processing complex of Ukraine is carried out. An assessment of the production and marketing activities of agro-clusters of the meat processing complex, taking into account foreign investment is fulfilled. The index of market conditions of sales of products of the subject of meat processing industry on the scale (value) of the net income received at the expense of the introduced innovative technologies in manufacture is calculated. The forecast value of the
\end{abstract}

polyvector change of the general integrated indicator of innovation and investment capacity of agro-clusters in the polarized space-time interval of the regional level is determined. It is concluded that innovations are vital factor of increasing the level of sales of products of meat processing subjects. It is proposed to implement the assessment of potential opportunities for innovation, organization of sales, communication and pricing policies.

Keywords Sales Market, Production and Sales Activities, Market Conditions, Innovations, Investments, Capacity, Meat Processing Complex

\section{Introduction}

A number of factors that affect the potential of the industry, the balance of market conditions and the mechanisms of market environment influences the formation and development of the market of meat products in the world. The system of interaction and economic relations of meat processing enterprises at different levels proves that there is a certain divergence of interests of economic subjects, which leads to a gap between supply and demand in the food market. Unfortunately, meat processing is no longer a priority area not only at the macro level, but also at the meso level. 
This is due to resource constraints and the lack of real state support for restoring the financial capabilities of the industry, as well as the prospects for the development of strategic partnerships based on the innovation and investment platform.

The imbalance of the system of interaction of market participants prevents the search for new formative levers to counteract the crisis phenomena of meat processing complex development in the polarized economic space of the regions. At the same time, the market of meat processing products is characterized by significant dependence on the external environment, in particular, on imports, customs requirements, and international product quality standards. Without such interaction, it is impossible to achieve the required level of quality and take a priority place in the world market.

The choice of strategic guidelines in the formation of mutually beneficial cooperation in international integration requires building the internal potential of the industry, under the influence of the innovation and investment mechanism, as only deep qualitative transformations can create an innovative model of economic growth of meat processing complex. At the same time, the study of the innovation process, motives and mechanisms of innovative renewal of the material base of the meat processing industry, analysis of favorable factors and obstacles to the successful implementation of innovations, encourages the need to form an innovative component in the structural transformations of the industry and the use of carefully verified criteria for the activation of innovative technologies for the production of meat products, adequate to market realities.

General issues of the theory of innovation and investment mechanism of securement for the development of production and the functioning of the market for research products were studied by many scientists. M. Malik [1], G. Mensch [2] and O. Mykhailovsko [3] characterized different types of innovative activity and explained their role in increasing the competitiveness of agro-industrial production. Yu. Oliinyk [4] and A. Peresada [5] investigated theoretical basis of the innovation and investment sphere. Practical issues of innovation and investment mechanism were explained by T. Polozova [6].

A large number of scientific works are devoted to the development and implementation of methodological tools for diagnostics in the field of innovation and investment. Investment-cash flow sensitivity was studied by S. Agca and A. Mozumdar [7], A. Ascioglu et al. [8], F.A. Al Sawalqa [9]. Management of innovation and investment were main subject in researches of P. Grechan et al. [10], A. Kosenko [11], D. Ben Amara [12], I. Kriuchkova and S. Filippova [13]. The variety of methodical approaches regarding management innovative processes was shown in studies of S. Labunska [14], L. Lihonenko [15], O. Manoilenko et al. [16], T. Skrypko and B. Miziuk [17],

\section{Yarmolenko and N. Polishchuk [18].}

Theoretical aspects of the functioning of food markets, in particular their features of functioning are discussed in the works of such scientists as T. Horodetska [19], Ya. Beznesiuk [20], N. Hurzhii [21], O. Krasnorutskyi [22], O. Kravchenko [23], M. Ginanneschi [24], N. Shelest [25], O. Sopotsko [26], C. Yuan and S. Ling [27], V. Gallego et al. [28], R. Ramón et al. [29]. However, the variety of approaches to determining the strategic directions of effective development of the sales market indicates the unresolved issues of the industry, in particular in the regional aspect and the state's influence on the creation of innovation and investment environment in the processing industry of meat processing complex.

The purpose of the study was to identify the determinants of Ukrainian sales market development of meat processing complex products that implement the parameters of innovation and investment capacity of local subjects in the innovation and investment system of the regional polarized space.

\section{Materials and Methods}

The development of the sales market for products on the innovation and investment platform at the regional level is based on a methodological approach and guidelines for assessing the scale of production and marketing activities of meat processing subjects and their innovation and investment capacity, which, according to the behavioral concept, is the main lever of continuity and efficiency of functioning of subjects. Development of methodological tools for comprehensive diagnostics of innovative opportunities of meat processing subjects among other industries operating in the agro-product subcomplex of regions is based on the dynamic trend of innovation and investment process and allows determining the imperatives of stabilizing market conditions in the environment.

We should note that the integrated indicator of innovation and investment capacity of the meat processing complex of the region $\left(I_{i i c}\right)$ is determined by formula (1) through a combination of the indicator of innovation and investment capacity $\left(E_{i i c}\right)$ and the integrated indicator of social and motivational software $\left(I_{s m u}\right)[15]$

$$
I_{i i c}=\sqrt{E_{i i c} \times I_{\text {smu }}}
$$

In turn, the indicator of innovation and investment capacity of the meat processing complex in the region $\left(\mathrm{E}_{i i c}\right)$ takes into account the complementarities of its components and is calculated by formula (2) [15]:

$$
E_{i i c}=\sqrt{I_{i n c} \times I_{i n v c}}
$$

where, $I_{i n c}-$ is an integral indicator of the innovative capacity of the subject of the meat processing complex in the region; $I_{i n v c}-$ is an integral indicator of the investment 
capacity of the meat processing complex of the region.

We have developed a comprehensive methodological approach to the systematic diagnosis of the time interval for sales of meat processing complex products in the region by the level of spatial polarization of innovation and investment capacity of the subject (Figure 1), which provides interrelated target priorities of market development in four-contour configuration: contour configuration classes - $(S 1, S 2)$, (i.e., high or low level of innovation and investment process of the subject in the regional market); structural-parametric configuration $(p 1, p 2, p 3)$ (i.e., the criteria of investment and innovation capacity of the subject and the ability of its employees to social and motivational support of the innovation and investment process $\left(I_{s m}\right)$ ); time configuration $-I_{i i c}$ (i.e., estimating the time interval $I_{i i c}$ in a dynamic trend, taking into account the limit of innovation and investment capabilities of the subject, given the high $S 1$ or low $S 2$ level of innovation and investment process); configuration of the forecast of polyvector change of level $I_{i i c}$ in time.
The contour recognition of classes of innovation and investment process of the subject on the basis of three indicators is offered, the choice and algorithm of calculation of which takes into account specific features of innovation and investment capacity with limited information flow. The set of recognizable class indicators is formed by indicators that characterize the efficiency of production and marketing activities, market conditions of sales of meat processing complex of the region, determined by the scale (value) of net income and return on investment. Based on the above provisions, the contour recognition of the meat processing industry in the sales market of products by classes of innovation and investment process is presented in Figure 2.

The set of indicators of contour recognition of classes of innovation and investment process of the subject in the sales market of products can be expanded (narrowed) and more detailed, depending on the formed information flow.

\begin{tabular}{|c|c|}
\hline \multirow{3}{*}{$\begin{array}{l}\text { Contour } 1 \\
\text { Formation of a } \\
\text { contour } \\
\text { configuration of } \\
\text { an estimation }\end{array}$} & Stage 1. Formation of contour recognition of classes $(S 1, S 2)$ \\
\hline & Stage 2. Formation of structural-parametric configuration $(p 1, p 2, p 3)$ \\
\hline & Stage 3. Formation of the matrix of information flow \\
\hline \multirow[b]{2}{*}{$\begin{array}{l}\text { Contour } 2 \\
\text { Estimation of a } \\
\text { contour } \\
\text { configuration in }\end{array}$} & $\begin{array}{l}\text { Stage } 4 . \text { Mathematical tools for estimating the vectors of the mean, covariance matrices } \\
\text { and estimating the total covariance matrix }\end{array}$ \\
\hline & $\begin{array}{l}\text { Stage } 5 . \text { Decision-making determining the logarithm of the action on the recognition of } \\
\text { the subject in the sales market of products with a high } S 1 \text { or low } S 2 \text { level of innovation } \\
\text { and investment process }\end{array}$ \\
\hline \multirow{4}{*}{$\begin{array}{l}\text { Contour } 3 \\
\text { Estimates of a } \\
\text { contour } \\
\text { configuration } \\
\text { over time }\end{array}$} & $\begin{array}{l}\text { Stage 6. Assessment of the functional capabilities of the subject in the sales market of products, } \\
\text { taking into account the spatial boundaries of the regional innovation and investment system }\end{array}$ \\
\hline & $\begin{array}{l}\text { Stage 7. Estimation of time space } I_{i i c} \text {, taking into account the dynamics of the } \\
\text { development of the sales market of products at the regional level }\end{array}$ \\
\hline & Stage 8. Calculation of the boundary of time space $I_{\text {iic }}$ \\
\hline & $\begin{array}{l}\text { Stage 9. Estimation of possibilities of the subject in the market of sale of production on } \\
\text { level of innovation and investment process in time space } I_{\text {iic ic interval }}\end{array}$ \\
\hline $\begin{array}{l}\text { Contour } 4 \\
\text { Prediction of } \\
\text { contour } \\
\text { configuration }\end{array}$ & $\begin{array}{l}\text { Stage 10. Determination of the predicted polyvector change } I_{i i c} \text { at the regional level, } \\
\text { which affects the space-time interval of product sales }\end{array}$ \\
\hline
\end{tabular}

Figure 1. Systematic diagnostics of the time interval for the sale of products of the meat processing complex in the region by the level of innovation and investment capacity 


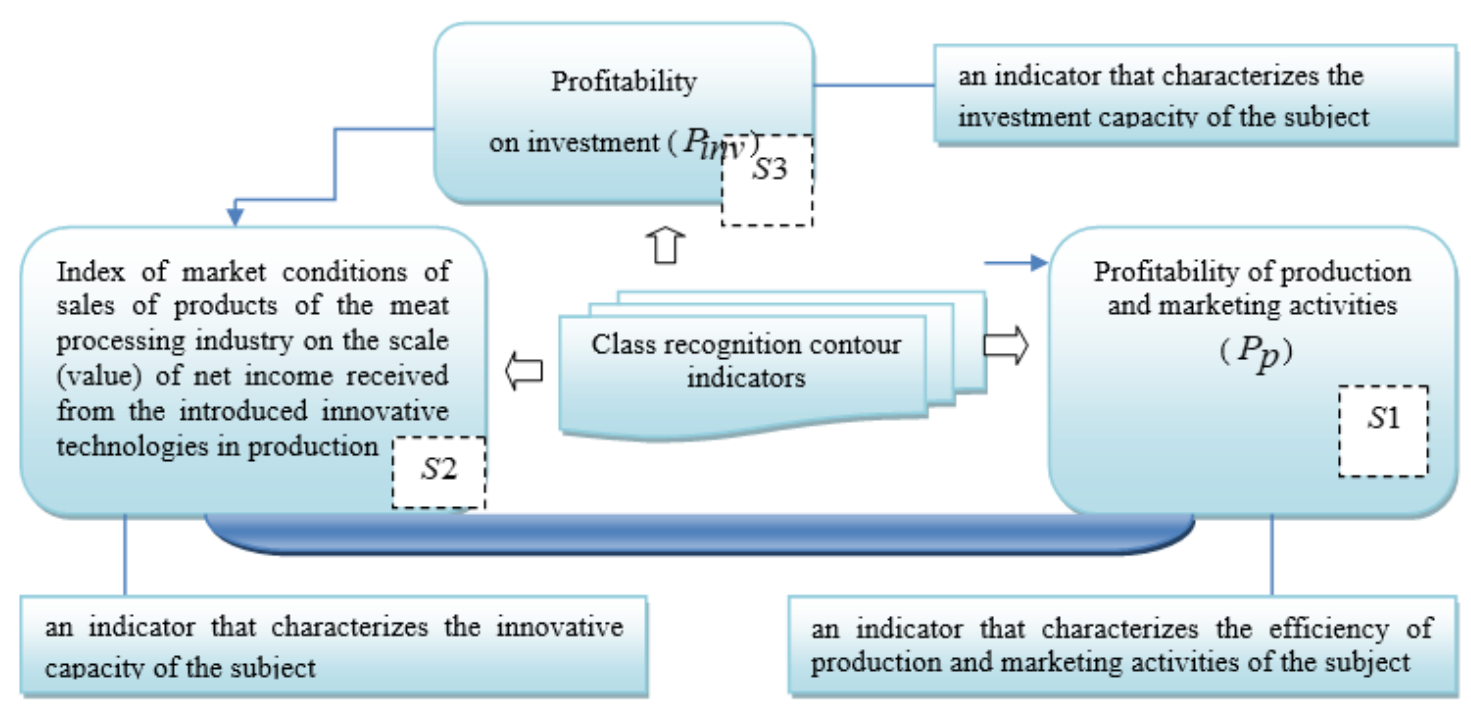

Source: developed by the authors according to data $[4 ; 5 ; 13 ; 14,16]$.

Figure 2. Indicators of the contour configuration of the recognition of the subjects of the meat processing complex of the region in the sales market of products by classes of innovation and investment process

Profitability of production and marketing activities of the subject of the meat processing complex of the region is calculated by formula (3) [16]:

$$
P_{p}=\frac{P_{g r}}{F A_{m}+F A_{\text {int }}}
$$

where, $P_{g r}$ - the amount of operating profit; $F A_{m}, F A_{\text {int }}$ - the value of tangible and intangible fixed assets of the meat processing industry; $R P$ - the value of working capital of the subject of the meat processing complex of the region.

\section{Results}

An important feature of the sales market of products of meat processing complex of the EU is its stability. It is common for companies to grow herds, processes and packs the meat themselves. The researchers create different technological solution for the new livestock sites [9;10]. A high level of production automation is a feature of successful manufacture [12].

The policy of investment support of innovations in the development of the meat processing complex enables the stabilization vector of market conditions and is part of the overall innovation policy, which determines the choice of the most effective investment instruments to increase their innovation and investment capacity in the market. As a rule, it is carried out in the following stages:

- determining the need (volume) for investing in innovation activities, especially in the initial stages of the innovation process, provided that the innovation is implemented through its own sources of investment. Based on a detailed and comprehensive analysis of the market situation of sales and production and marketing activities of the subject, we calculate the potential of technological capacity, which is not enough or needs to be upgraded to meet market demand for products (or determine the need for investment resources to promote innovation on the market). This stage is very important, because insufficiently formed amount of investment resources leads to a prolongation of the period of innovation process and "aging" of innovations), and their excess - reduces the rate of return and return on investment;

- determining the list of possible sources (forms) of investment and choosing the optimal ones;

- control over the inflow and target allocation of investment resources, as well as their effective use.

The term of implementation of innovation and investment projects should promote the economic development of the meat processing industry and provide additional value for cash flow in the form of return on investment and depreciation charge.

In order to determine the dominant levers in the structure of the polarized space of the regional innovation and investment system, taking into account the time interval of the accelerated development of the sales market of products of separate subject of a meat-processing complex, it is offered to use an index of a market conjuncture of production on scale (value) of the net income received at the expense of the introduced innovative technologies in production $\left(\mathrm{I}_{r p}\right)$ - the ratio of net income received from innovations in the production of meat products of the subject to the maximum value of net income from innovations in production in the diagnostic space of the subjects of the industry (formula (4)) [16]: 


$$
I_{r p}=\frac{C I_{i t}^{j}}{C I_{i t(\max )}}
$$

where, $C I_{i t}^{j}-$ net income received from innovations in the production of meat products of the $\mathrm{j}$-th subject of the industry; $C I_{i t(\max )}^{j}$ - the maximum value of net income from innovations in the production of meat products in the diagnostic space of the industry.

The positive dynamics of this indicator is its increase over time. The maximum value of the index corresponds to the optimal sales situation of the product of the subject under study and its competitive advantages among others.

Profitability on investment $\left(P_{p}\right)$ is calculated by formula (5) $[16]$ :

$$
I_{r p}=\frac{A R_{v}}{I n_{i p}}
$$

where, $\mathrm{AR}_{\mathrm{V}}$ - the value of gross profit; $\mathrm{I} n_{\mathrm{ip}}$ - the amount of investment in the innovation process.

Contour recognition of classes of innovation and investment process of the subject of meat processing complex of the region and potential opportunities in the market of production, on aggregate indicators (S1andS2) allows to define their integral level (L), according to formula (6) [18]:

$$
L=\sqrt[n]{\prod_{l=1}^{n} S 1}
$$

where, $S 1$ - the $1_{t h}$ indicator of the contour configuration of class recognition; $\mathrm{n}-$ the number of indicators of the contour configuration of class recognition.

Accordingly, the calculation of the integrated indicator (L) has the form (formula (7)) [18]:

$$
L=\sqrt[3]{\prod_{l=1}^{3} S 1}=\sqrt[3]{S 1 \times S 2 \times S 3}=\sqrt[3]{P_{p} \times I_{r p} \times P_{i n v}}
$$

At the same time, the gradation of the subjects of the meat processing complex in the region according to the classes of innovation and investment process - S1 and S2 (Harrington scale), allows to distribute them according to the modified criteria (Table 1).

\begin{tabular}{|c|c|c|c|}
\hline $\begin{array}{c}\text { Description of } \\
\text { gradations }\end{array}$ & Criterion & $\begin{array}{l}\text { Description of contour } \\
\text { gradations of class } \\
\text { recognition }\end{array}$ & Criterion \\
\hline \multicolumn{2}{|c|}{ Traditional scale } & \multicolumn{2}{|c|}{ Modified scale (author's approach) } \\
\hline Very high & $0.8-1.0$ & \multirow{3}{*}{$\begin{array}{l}\text { High (sufficient) level of } \\
\text { innovation and investment } \\
\text { process }(S 1)\end{array}$} & \multirow{3}{*}{$0.38-1.00$} \\
\hline High & $0.64-0.8$ & & \\
\hline Average & $0.37-0.64$ & & \\
\hline Low & $0.2-0.37$ & \multirow{2}{*}{$\begin{array}{l}\text { Low level of innovation } \\
\text { and investment process } \\
\qquad(S 2)\end{array}$} & \multirow{2}{*}{$0.0-0.37$} \\
\hline Very low & $0.0-0.2$ & & \\
\hline
\end{tabular}

Table 1. The scale of contour recognition of the subjects of the meat processing complex by classes of innovation and investment process and their potential opportunities in the sales market of products

Source: developed by the authors

Thus, the formed contour of class recognition will have the following mathematical interpretation (formula (8)) [18]:

$$
S 1 \in 0.38 \leq L \leq 1 ;, S 2 \in\left[0.0 \leq \sqrt[3]{\prod_{l=1}^{3} S 1} \leq 0.37\right]
$$

In particular, if according to the results of calculations only one subject of the meat processing industry is obtained, which satisfies the requirements of the sales market of products on the basis of innovation and investment process in production and marketing activities, then at least one potential subject must be added to the class contour recognition, which ranks second in the ranking of the integrated indicator. This will increase the reliability of the structural polarization of the regional innovation and investment system and its gradation in the external environment.

The formation of the structural and parametric configuration of innovation and investment capacity of the subject of meat processing complex, according to three integrated indicators, which are interrelated with the characteristics of the sales market and the ability of employees to socially motivated innovation and investment process is presented in Figure 3. 


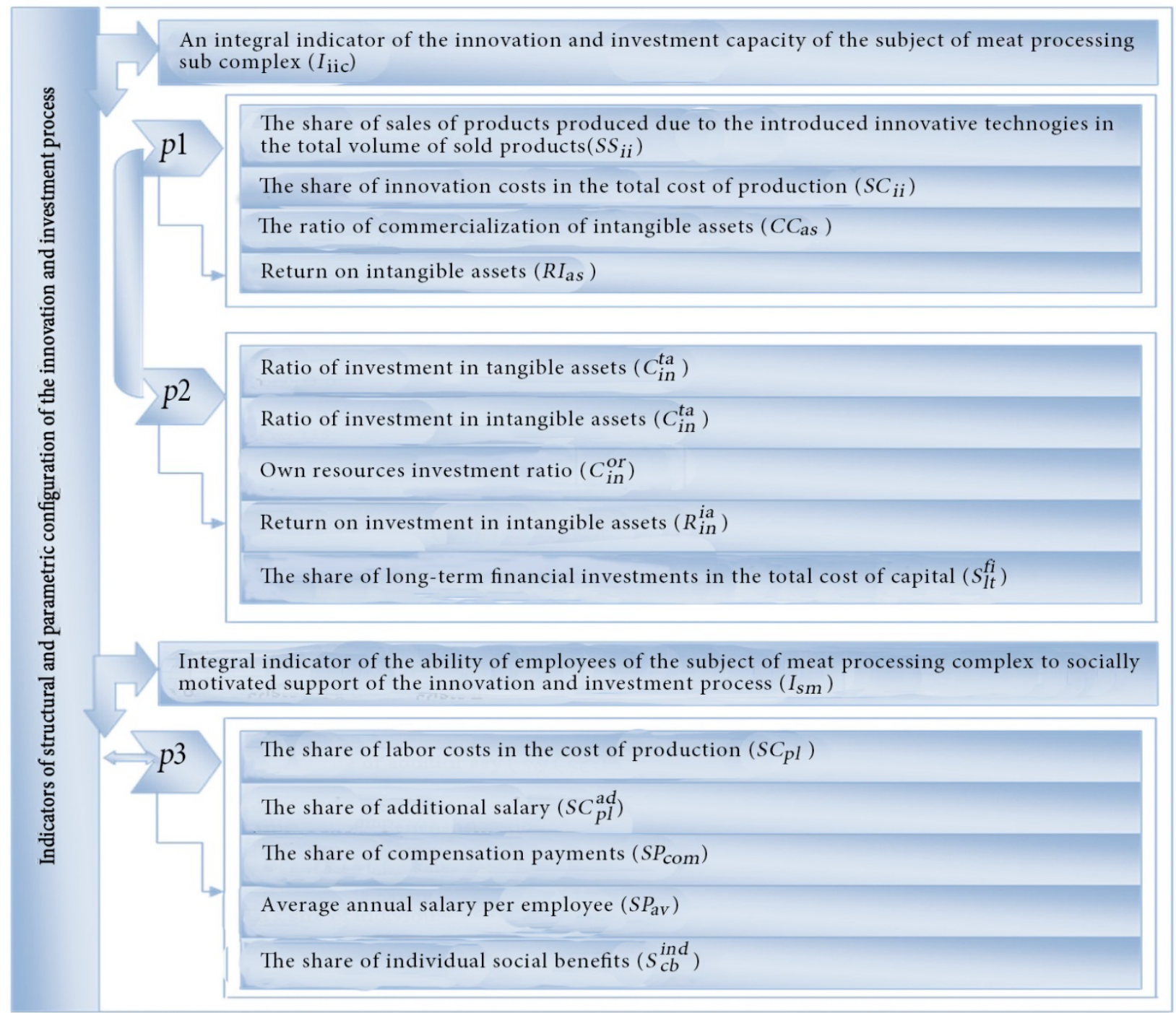

Figure 3. The system of indicators of structural and parametric configuration of the innovation and investment process and the potential of the subject of meat processing complex in the sales market of products

The obtained partial values are normalized in order to bring them to one dimensional value (formula (9)) [30]:

$$
P_{\text {ind }}=\frac{P_{\text {ind }}^{f}}{\sum_{i=1}^{n} P_{\text {ind }}^{f}} ; i=\overline{1, n}
$$

where, $\mathrm{P}_{\text {ind }}$ - partial indicator, according to the calculations of the actual data flow of the meat processing subject; $n$ the number of meat processing subjects included in the diagnostic configuration.

The total integrated indicator of the structural-parametric configuration is calculated by formula (10) [18]:

$$
I_{(p 1, p 2, p 3)}=\frac{\sum_{j=1}^{m} P_{i n d}}{m}
$$

where, $m$ - the number of partial normalized indicators that are part of the integrated indicator.

System diagnostics $I_{i i c}$ in the space - time aspect (see Figure 1) allows forming a matrix of information flow and predicting polyester development $I_{i i c}$. In this case, if the value of the derivative $\frac{\partial L n \hat{L}(t)}{\partial t} \leq 0$, then there is a decrease in level $I_{i i c}$, if $\frac{\partial L n \hat{L}(t)}{\partial t} \geq 0$, then there is a rise. In a situation when the derivative is equal to zero $\frac{\partial \operatorname{Ln} \hat{L}(t)}{\partial t}=0$, uniform development $I_{i i c}$ is fixed.

Observations in the time aspect can be started from any point in time tk, and it is important to carry out measurements $\operatorname{LnL}^{\gamma}(\mathrm{t})$ at regular intervals $\Delta \mathrm{t}$. That is, if the observation begins from the moment the meat processing subject enters the market, taking into account its class of innovation and investment process in the polarized space of the regional innovation and investment system, then for a long period of time the function change $\operatorname{LnL}^{\gamma}(t)$ will correspond to the life cycle curve of the innovation and investment project of the subject.

The revealed dynamic trend of the behavior of the generalized indicator of the time interval for the sale of products of the subject of meat processing complex of the region by the level of innovation and investment capacity 
in the polarized space, with the reliability of the information flow, allows predicting the level Iiic. To do this, it is more appropriate to use the method of trend extrapolation.

The generalized results of diagnostics Iiic in the forecasted space-time aspect are presented in Table 2. This approach allows to carry out quantitative identification of a condition of development of the market of meat processing complex of region as a whole and to define potential possibilities of separate subject of industry in polarization structure of external environment, which is a platform for determining the predicted polyester change of its level $\mathrm{I}_{i i c}$.

Table 2. Interpretation of forecasting the spatio-temporal interval of sales of products of the subject of meat processing complex by level $I_{\text {iic }}$ in the polarized innovation and investment system of the region

\begin{tabular}{|c|c|c|}
\hline Level of diagnosis & $\begin{array}{c}\text { Value } \\
\operatorname{Ln} \hat{L}(t)\end{array}$ & Interpretation of the forecast $I_{i i c}$ \\
\hline \multirow{3}{*}{$\begin{array}{l}\text { Forecast } \\
\text { diagnostics in } \\
\text { space (contour 2) }\end{array}$} & $\operatorname{Ln} \hat{L}(t) \geq 0$ & $\begin{array}{l}\text { The subject has a high innovation and investment capacity in the sales market of products and a high } \\
\text { level of innovation and investment process }(S 1) \text { in the regional polarized space of the innovation and } \\
\text { investment system }\end{array}$ \\
\hline & $\operatorname{Ln} \hat{L}(t)=0$ & $\begin{array}{l}\text { The subject has a threshold value of innovation and investment capacity of sales of products on the } \\
\text { market, but a low level of innovation and investment process }(S 2) \text { in the regional polarized space of } \\
\text { the innovation and investment system }\end{array}$ \\
\hline & $\operatorname{Ln} \hat{L}(t) \leq 0$ & $\begin{array}{l}\text { The subject has a low innovation and investment capacity in the sales market of products and a low } \\
\text { level of innovation and investment process }(S 2) \text { in the regional polarized space of the innovation and } \\
\text { investment system }\end{array}$ \\
\hline \multirow{3}{*}{$\begin{array}{l}\text { Forecast } \\
\text { diagnostics in time } \\
\quad(\text { contour } 3)\end{array}$} & $\operatorname{Ln} \hat{L}(t) \geq 0$ & $\begin{array}{l}\text { In the time interval } t_{k} \text { there is a high innovation and investment capacity of the subject in the sales } \\
\text { market of products and a high level of innovation and investment process }(S 1) \text { in the regional } \\
\text { polarized space of the innovation and investment system }\end{array}$ \\
\hline & $\operatorname{Ln} \hat{L}(t)=0$ & $\begin{array}{l}\text { The time interval } t_{k} \text { and innovation-investment capacity of the subject in the sales market of } \\
\text { products have a threshold value, but a low level of innovation-investment process (S2)in the } \\
\text { regional polarized space of the innovation-investment system }\end{array}$ \\
\hline & $\operatorname{Ln} \hat{L}(t) \leq 0$ & $\begin{array}{l}\text { In the time interval } t_{k} \text { there is a low innovation and investment capacity of the subject in the sales } \\
\text { market of products and a low level of innovation and investment process }(S 2) \text { in the regional } \\
\text { polarized space of the innovation and investment system }\end{array}$ \\
\hline \multirow{3}{*}{$\begin{array}{c}\text { Forecast } \\
\text { diagnostics of } \\
\text { polyvector } \\
\text { development } \\
\text { (contour 4) }\end{array}$} & $\frac{\partial \operatorname{Ln} \hat{L}(t)}{\partial t} \geq 0$ & $\begin{array}{l}\text { There is an increase in innovation and investment capacity of the subject in the sales market of } \\
\text { products and a high level of innovation and investment process }(S 1) \text { in the regional polarized space } \\
\text { of innovation and investment system }\end{array}$ \\
\hline & $\frac{\partial \operatorname{Ln} \hat{L}(t)}{\partial t}=0$ & $\begin{array}{l}\text { There is a threshold value of innovation and investment capacity of the subject in the sales market of } \\
\text { products, but a low level of innovation and investment process }(S 2) \text { in the regional polarized space } \\
\text { of the innovation and investment system }\end{array}$ \\
\hline & $\frac{\partial \operatorname{Ln} \hat{L}(t)}{\partial t} \leq 0$ & $\begin{array}{l}\text { There is a decrease in innovation and investment capacity of the subject in the sales market of } \\
\text { products and low level of innovation and investment process }(S 2) \text { in the regional polarized space of } \\
\text { the innovation and investment system }\end{array}$ \\
\hline
\end{tabular}

Source: developed by the authors

We should note that the demand for products of the meat processing subcomplex changes under the influence of determinants (Figure 4).

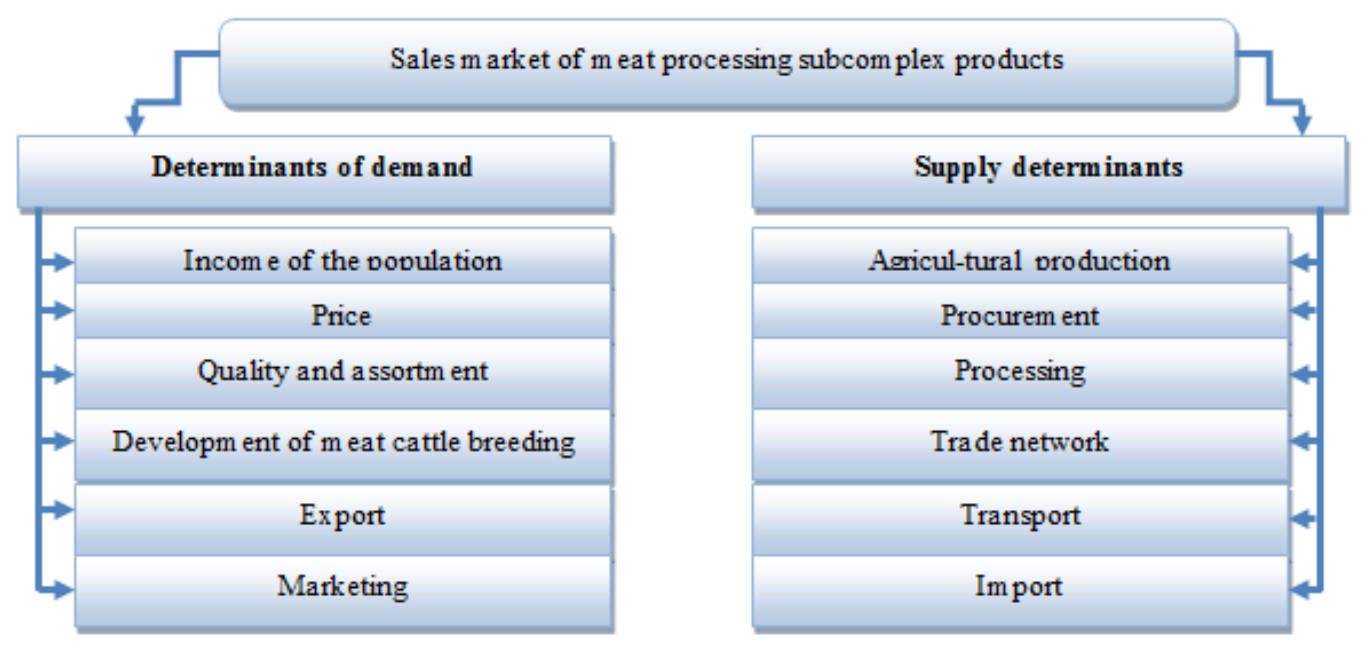

Source: developed by the authors

Figure 4. Determinants of sales market development of meat processing complex products 
The determinant of the impact on demand is the unit price. Therefore, the demand function can be expressed by equation (11) [22]:

$$
Q D=f(P)
$$

where, QD - the amount of demand that can be purchased by the buyer; $\mathrm{P}$ - unit price.

Non-price determinants that affect the demand for meat products include: economic (change in real needs, real monetary income, prices for substitutes, complementary goods); social (level of universal culture, subculture, traditions and customs, economic and political culture); demographic (changes in population structure (by sex and age, family size, occupation, education, etc.)), psychological (belonging to a certain social class, lifestyle (tastes and preferences of traditionalists, aesthetes) personality type (general, authoritarian nature)).

Accordingly, the demand function can be represented as follows [22]:

$$
Q D=f\left(P, P_{1} S, P_{n} S, P_{1} C, P_{m} S, I, Z, W, N, B \ldots\right)
$$

where, QD - the volume of demand; P - unit price; PS - the price of the substitute products; PC - the price of the complete good; $\mathrm{Z}$ - tastes and preferences; $\mathrm{W}$ - objective conditions of consumption; $\mathrm{N}$ - consumer expectations; $\mathrm{B}$ - other factors.

Supply changes, as well as demand, under the influence of not only prices but also non-price determinants: prices for resources (energy, raw materials, labor), which are production costs; technological changes; time period; taxes and subsidies; prices for interconnected products; number of sellers. The formative model of market development of meat processing complex should be identified as an interconnected set of quantitative and qualitative components that provide the calculation of sectoral and market criteria, construct integral values of changes in key parameters of the aggregate state of market development on the basis of effective innovation and investment system in the polarized space of the region and its reorientation from uncoordinated pricing methods to scientifically sound principles of providing added value [22]. The process of systematic comparison of sectoral and general market criteria with the "evaluation basis" affects the evaluation results, which are presented in Table 3.

\begin{tabular}{|c|c|c|c|}
\hline $\begin{array}{l}\text { The name of the criterion } \\
\text { (indicator) }\end{array}$ & $\begin{array}{l}\text { Normative } \\
\text { value }\end{array}$ & $\begin{array}{l}\text { "Evaluation } \\
\text { basis" }\end{array}$ & $\begin{array}{l}\text { Characteristics of the criterion } \\
\text { (indicator) }\end{array}$ \\
\hline \multicolumn{4}{|c|}{ Financial unit } \\
\hline $\begin{array}{c}\text { Profitability of } \\
\text { products }\end{array}$ & $\begin{array}{l}\text { compared to the "evaluation } \\
\text { basis" }\end{array}$ & basic & $\begin{array}{l}\text { change in the profitability of meat } \\
\text { products in the dynamics }\end{array}$ \\
\hline $\begin{array}{c}\text { Profitability of } \\
\text { operating activities }\end{array}$ & $\begin{array}{l}\text { compared to the basic } \\
\text { indicator }\end{array}$ & basic & $\begin{array}{l}\text { change in the profitability of meat } \\
\text { market subjects in the dynamics }\end{array}$ \\
\hline \multicolumn{4}{|c|}{ Cross-sectoral link unit } \\
\hline $\begin{array}{l}\text { Dynamics of trade flows between market } \\
\text { sectors }\end{array}$ & increasing & basic & $\begin{array}{l}\text { change in trade flows between market } \\
\text { sectors }\end{array}$ \\
\hline The ratio of meat exports to its production & $\begin{array}{l}\text { within the optimal level of food } \\
\text { security }\end{array}$ & $\begin{array}{l}\text { basic } \\
\text { target }\end{array}$ & $\begin{array}{l}\text { the level of export orientation, the } \\
\text { impact of world demand on the } \\
\text { development of the domestic market }\end{array}$ \\
\hline The degree of market openness & $\begin{array}{c}<40 \% \text { the territory of the } \\
\text { country is the geographical } \\
\text { boundaries of the market } \\
>40 \% \text { a sign of market } \\
\text { openness }\end{array}$ & normative & $\begin{array}{c}\text { the ratio of imports of meat products to } \\
\text { sales }\end{array}$ \\
\hline \multicolumn{4}{|c|}{ Food security unit } \\
\hline Meat supply indicator [18] & $\begin{array}{l}80 \mathrm{~kg} \text { of meat and meat products } \\
\text { per capita }\end{array}$ & normative & sufficiency of meat \\
\hline $\begin{array}{l}\text { The share of expenditures on meat and } \\
\text { meat products in the structure of total } \\
\text { expenditures of the population [18] }\end{array}$ & decreasing & united & economic affordability of meat \\
\hline
\end{tabular}

Table 3. The system of evaluation criteria (indicators) for the development of the sales market of products of meat processing complex

Source: systematized by the authors [22; 26] 
The value of the "evaluation basis" is based on the study of retrospective and promising areas of sales market development, taking into account global market trends.

To substantiate the strategic directions of sales market development of products using modeling methods in different scenarios of the innovation and investment system in the polarized space of the region allows its regulation at the macro level.

To activate the innovation and investment system in the regional polarized space, it is necessary to adhere to the guidelines and take into account the potential of innovation and investment activity of the meat processing complex in order to ensure the level of food security. In accordance with the proposed methodological approach of multilevel diagnostics $I_{i i c}$ of the polarized space of the innovation and investment system of the regions of Ukraine, we will quantitatively identify agro-clusters of meat processing complex and determine their forecast polyvector changes $\mathrm{I}_{i i c}$ by classes of innovation and investment process.

The implementation of the proposed approach was carried out on 18 agro-clusters of the meat processing complex located in 18 regions of Ukraine. In order to form a structural and parametric configuration by classes of innovation and investment process, 7 agro-clusters were selected, which carried out technological innovations in production and marketing activities during 2017-2019 (Figure 5).

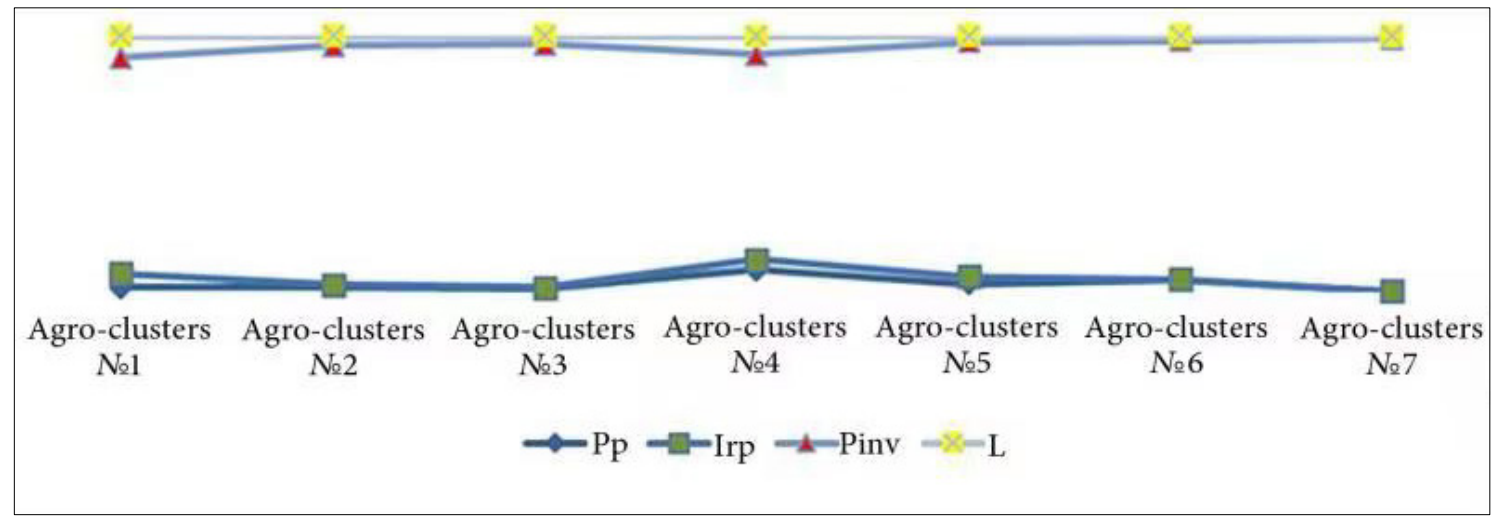

Source: calculated by the authors

Figure 5. The system of indicators of structural and parametric configuration of Agro-clusters of the meat processing complex in the polarized space of the innovation and investment system of the regions of Ukraine, on average for 2017-2019

Based on the calculations, a matrix was constructed in the time interval of 2017-2019 of the diagnostic procedure. According to the mathematical tools, the vectors of the mean and general covariance matrix are determined. The vectors of the averages ${ }^{-}{ }_{-}{ }_{1},{ }^{-}{ }_{-} \_$in each time interval are:

2017

$\overline{\mathrm{a}}_{1}=\left(\begin{array}{l}\mathrm{x}_{1}^{(1)} \\ \mathrm{x}_{2}^{(1)}\end{array}\right)=\left(\begin{array}{l}0.2240 \\ 0.05536\end{array}\right) ; \quad \bar{a}_{2}=\left(\begin{array}{l}\mathrm{x}_{1}^{(2)} \\ \mathrm{x}_{2}^{(2)}\end{array}\right)=\left(\begin{array}{l}0.0547 \\ 0.2902\end{array}\right)$

2018: $\quad \overline{\mathrm{a}}_{1}=\left(\begin{array}{l}\mathrm{x}_{1}^{(1)} \\ \mathrm{x}_{2}^{(1)}\end{array}\right)=\left(\begin{array}{c}0.2603 \\ 0.3818\end{array}\right) ; \quad \bar{a}_{2}=\left(\begin{array}{c}\mathrm{x}_{1}^{(2)} \\ \mathrm{x}_{2}^{(2)}\end{array}\right)=\left(\begin{array}{c}0.0772 \\ 0.3120\end{array}\right)$

2019: $\quad \overline{\mathrm{a}}_{1}=\left(\begin{array}{l}\mathrm{x}_{1}^{(1)} \\ \mathrm{x}_{2}^{(1)}\end{array}\right)=\left(\begin{array}{l}0.2640 \\ 0.3925\end{array}\right) ; \quad \bar{a}_{2}=\left(\begin{array}{l}\mathrm{x}_{1}^{(2)} \\ \mathrm{x}_{2}^{(2)}\end{array}\right)=\left(\begin{array}{l}0.0321 \\ 0.2792\end{array}\right)$

Covariance matrices ${ }^{-} \mathrm{M} \_1,{ }^{-} \mathrm{M} \_2$ have the following form:

2017: $\quad \bar{M}_{1}=\left(\begin{array}{ll}0.0238 & 0.0492 \\ 0.0492 & 0.1016 \\ 0.0056 & 0.0115\end{array}\right) ; \quad \bar{M}_{2}=\left(\begin{array}{ccc}0.0022 & 0.0070 \\ 0.0070 & 0.1302 \\ 0.0008 & 0.0058\end{array}\right)$

2018: $\quad \bar{M}_{1}=\left(\begin{array}{ll}0.0217 & -0.0502 \\ 0.0502 & 0.1159 \\ 0.0067 & 0.0155\end{array}\right) ; \quad \bar{M}_{2}=\left(\begin{array}{ll}0.0124 & 0.0190 \\ 0.0190 & 0.1248 \\ 0.0006 & 0.0108\end{array}\right)$

2019: $\quad \bar{M}_{1}=\left(\begin{array}{ll}0.0318 & 0.0633 \\ 0.0633 & 0.1260 \\ 0.0115 & 0.0229\end{array}\right) ; \quad \bar{M}_{2}=\left(\begin{array}{ll}0.0004 & 0.0063 \\ 0.0063 & 0.1379 \\ 0.0006 & 0.0112\end{array}\right)$

General covariance matrices $\bar{M}$ have the following form: 


$\begin{aligned} \text { 2017: } & \bar{M}=\left(\begin{array}{ll}0.0117 & 0.0267 \\ 0.0267 & 0.1708 \\ 0.0014 & 0.0012\end{array}\right) ; \\ \text { 2018: } & \bar{M}=\left(\begin{array}{ll}0.0211 & 0.0391 \\ 0.0391 & 0.1712 \\ 0.0032 & 0.0046\end{array}\right) ; \\ \text { 2019: } & \bar{M}=\left(\begin{array}{ll}0.0132 & 0.0316 \\ 0.0316 & 0.1883 \\ 0.0040 & 0.0021\end{array}\right)\end{aligned}$

Predictive polyvector changes of the general integrated indicator of innovation and investment capacity Iiic in relation to the integrated indicator of social and motivational support of the innovation and investment process in the production and marketing activities of agro-clusters of meat processing subcomplex 7 of the regions of Ukraine in 2020-2022 are presented in Figure 6.

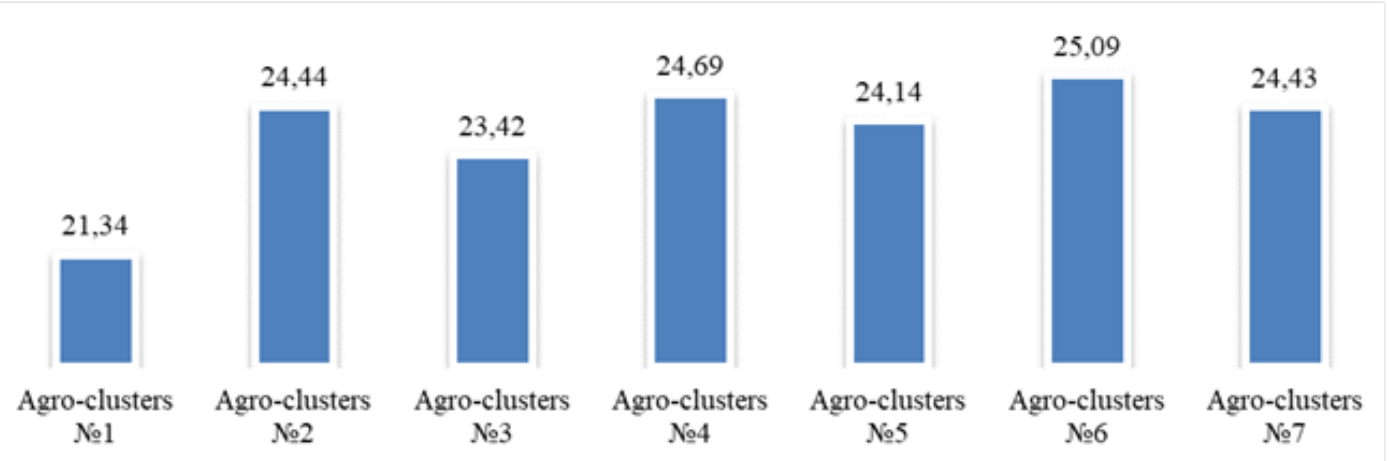

Source: calculated by the authors

Figure 6. Forecast polyvector changes of the general integrated indicator Iiic of agro-clusters in the space-time interval of sale of meat processing products of regional level in 2020-2022.

Thus, 7 agro-clusters of the meat processing complex in the regional polarized space of the innovation and investment system of Ukraine can be attributed to S1 (with a high level of innovation and investment process), as the value of the indicator I $\mathrm{iic} \geq 0$. Moreover, this trend persists during the forecast period of 2020-2022. This proves that the subjects can fully ensure the development of production and marketing activities with a constant increase in their position in the market conditions of both domestic and foreign markets and use direct foreign investment to balance own and borrowed sources in the investment of industry.

\section{Discussion}

Innovative transformation in the market environment makes strict demands to increase the efficiency of available resources and areas of development and strengthening of innovation and investment potential, reducing production costs, improving the quality of goods. Accordingly, the effectiveness of the mechanism of reproduction of market conditions for the products of the meat processing complex is impossible without the use of the resource base. It characterizes not the entire stock of a particular resource, but only that part of it, which is involved in the innovation and investment process of production, given the economic feasibility of innovation, and includes not only the existing system of resources but also innovation and investment resources and their sources.

The regional space of the meat market in Ukraine, the end result of market participants, is formed on the platform of rational use of limited resources, as well as timely response of the infrastructure of the meat processing complex to market fluctuations when changing the effects of factors which determine it. At the same time, the polarized space of the sales meat market has to meet the needs of consumers in these types of products in accordance with the established regulatory volumes, while maintaining the possibility of expanded reproduction of the industry and food security in the short and long term.

Thus, after the decline in meat processing production in Ukraine since 2017, innovation and investment processes in the industry have accelerated (in 2019 there is an increase of $15.5 \%$ compared to 2015). The reason for this is a change in the structure of production - a reduction in the production of beef and pork in favor of poultry meat [31; 32].

Ukrainian producers have potential opportunities to enter world markets for beef products in the United States, Germany and Switzerland. One of the important aspects of state policy in the meat processing and food industries in general is the composition, dynamics and structure of imports and exports of meat products in Ukraine (Figure 
7-8).

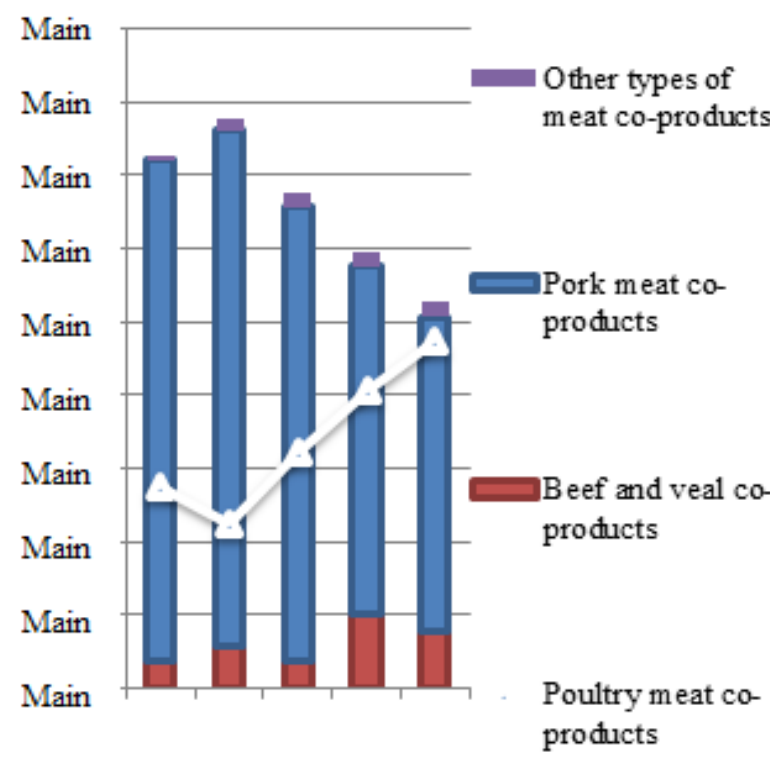

Source: compiled by the authors according to data [30]

Figure 7. Imports of meat processing products in Ukraine, $\%$

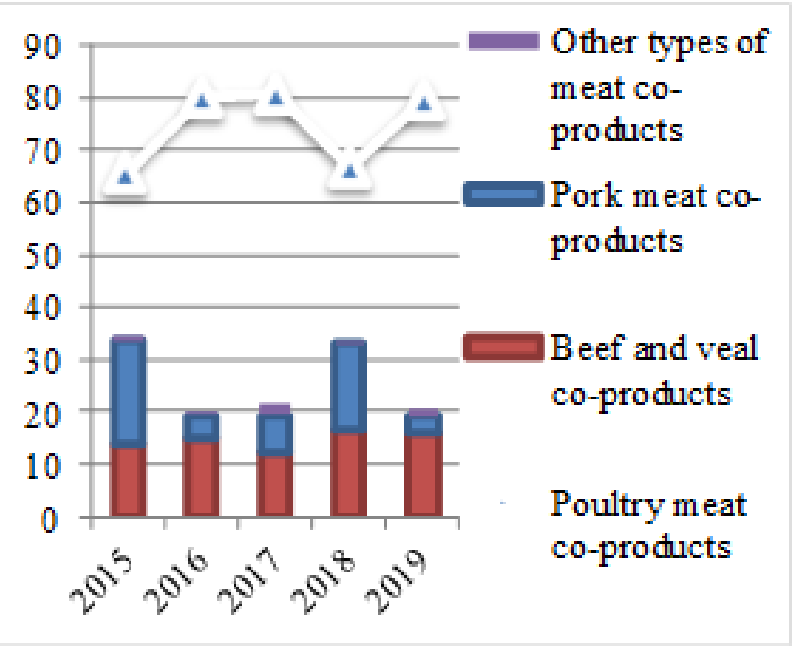

Figure 8. Exports of meat processing products in Ukraine, \%

Thus, the export of poultry meat co-products in 2015-2019 increased by 66\%. Poultry products are supplied to Iraq, Egypt, EU countries. In general, exports of meat processing co-products increased by $58.6 \%$ during the study period. At the same time, the volume of exports of pork co-products decreased by 4.5 times, beef - by $64.5 \%$.

The polarized space of formation of raw material base for sale of meat co-products in agro-clusters of meat processing complex, on average for one region of Ukraine, is formed at the local level, which depends on domestic and foreign market conditions (Figure 9).

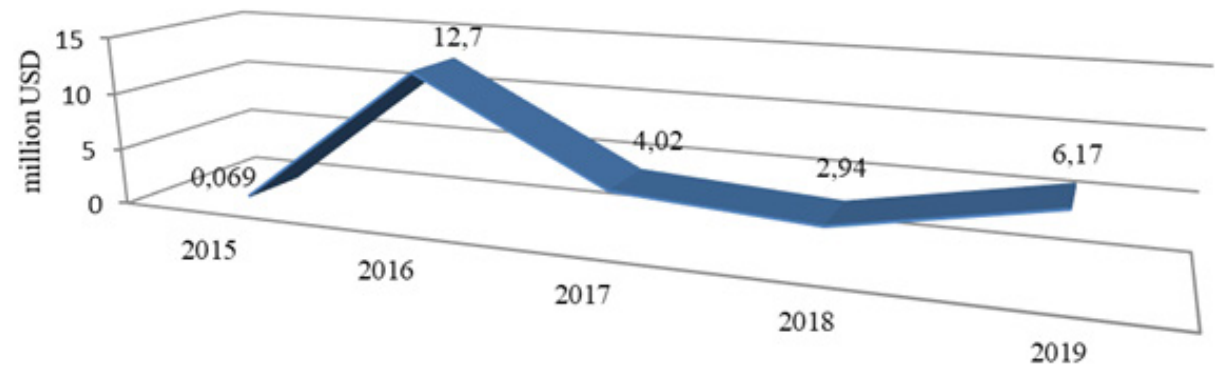

Source: compiled by the authors according to data [6;25;26]

Figure 9. Raw material base for the sale of meat co-products of agro-clusters of meat processing complex on average per one region of Ukraine, 2015-2019, million USD

The market of meat processing complex is a holistic, open system, which, firstly, increases the innovation and investment capacity of subjects in the internal and external environment, secondly, promotes active production of innovative products, and thirdly, reduces the cost of technological chain due to regulated profitability in intermediate links, increasing the efficiency of the innovation and investment process. The formation of a unified approach to the priority areas of sales, which allows attracting investment to reduce the cost of promoting innovative products in accordance with European standards leads to agro-clusters of the meat processing industry, increase existing resources by introducing new technologies.

It should be noted that the innovation process in production and marketing activities, due to the capitalized profits invested by the agro-cluster meat processing complex on average per region in Ukraine allows to ensure a sufficient economic effect (Figure 10). 


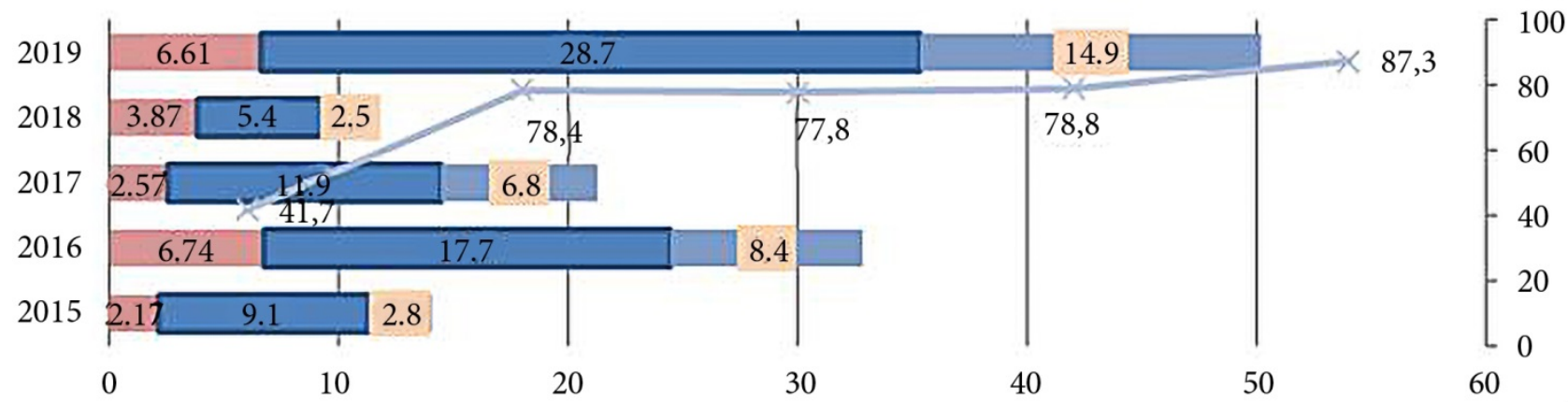

Capitalized return on investment in the innovation process, million USD

The level of profitability of economic activity, \%

The level of profitability of operating activities, \%

$\rightarrow$ The share of investment costs in the innovative process of meat processing, \%

Source: compiled by the authors according to data [30; 33; 34]

Figure 10. Innovation and investment process of production and marketing activities of agro-clusters of the meat processing complex on average per one region of Ukraine

Given that the regional polarized space of innovation and investment system in ensuring the balance of sales of agro-cluster meat processing complex in one region of Ukraine, under conditions of successful foreign trade, intensifies the restructuring of the industry and optimizes the intermediary structure of wholesale and retail distribution by type and place, reorienting the interests of the wholesale intermediary to the meat producer through the creation of a network of wholesale and retail complex at the local level. At the same time, the development of Ukrainian agro-clusters of the meat processing complex, with the participation of foreign capital, allows for a low degree of risk, rapid payback of initial costs for innovative processes of production and marketing activities for foreign investors (Figure 11-12).

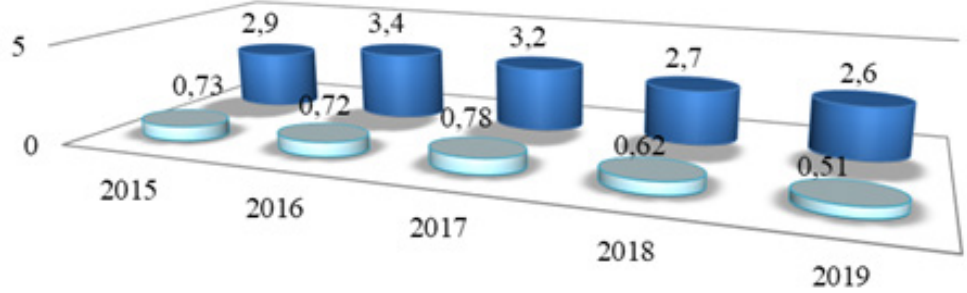

$\square$ Agriculture, billion USD $\quad$ Meat processing subcomplex, billion USD

Source: compiled by the authors according to data [30; 33; 34]

Figure 11. Volume of foreign direct investment in the agro-industrial complex of Ukraine, billion USD

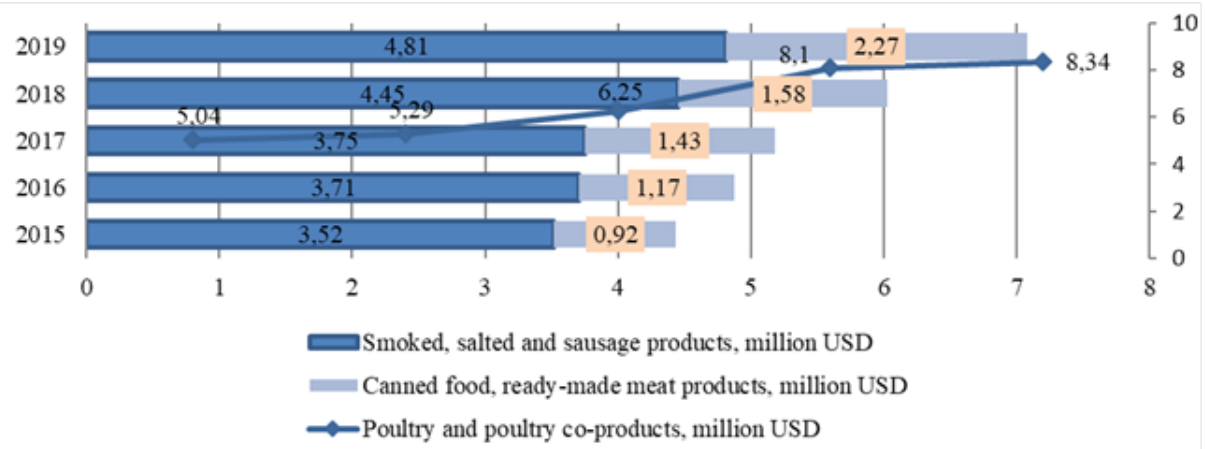

Source: compiled by the authors according to data [30; 33; 34]

Figure 12. Production and marketing activities of the agro-cluster meat processing complex under the condition of attracting foreign investments in Ukraine 


\section{Conclusions}

Developed comprehensive methodological approach allowed characterizing the sale of meat processing complex products in Ukraine. 7 agro-clusters of the meat processing complex in the regional polarized space of the innovation and investment system were used to construct a matrix in the time interval of 2017-2019 of the diagnostic procedure. These calculations became a basis for presenting predictive polyvector changes of the general integrated indicator of innovation and investment capacity. The main tendencies of contemporary Ukrainian sales market development and its perspectives were identified.

There are some limitations of the study. The implementation of the proposed approach was carried out in 18 regions of Ukraine. Out on 18 agro-clusters of the meat processing complex, 7 agro-clusters were selected in order to form a structural and parametric configuration by classes of innovation and investment process.

Innovation and investment components in the regional polarized space should be considered in a comprehensive unity. At the same time, without innovations it is almost impossible to increase the level of sales of products of meat processing subjects in general, without investment - to initiate and implement changes in the technological process, in order to intensify the innovation and investment process. Therefore, the potential opportunities for the development of the market for meat products in the context of the economic formation process requires the state to properly regulate investment, and the stimulation of investment activities should be considered in the context of the national economy development strategy on an innovative basis.

No less important, from our point of view, is the marketing platform in the regional innovation and investment system. It should be activated in the system for the development of the meat products market, using marketing tools that maximize the expected effect of sales of products (technology) and is manifested in the full satisfaction of consumer needs to increase and capitalize profits by agro-clusters. The need for marketing support is determined by the strengthening of market orientation of the industry. Given this, we consider it necessary to implement at the stages of evaluation of the innovation and investment process of the meat processing complex the assessment of potential opportunities for innovation, organization of sales, communication and pricing policies.

\section{REFERENCES}

[1] M. I. Malik. Innovative activity as a component of the strategy of increasing the competitiveness of agro-industrial production, Economics of Agro-Industrial Complex, Vol. 5, 155-157, 2005.
[2] G. Mensch. Stalemate in Technology: Innovations Overcome the Depression, Cambridge, Ballinger, 1979.

[3] O. V. Mykhailovsko. World experience of state support of innovation processes, Actual Problems of Economy, Vol. 11, 101-109, 2005

[4] Yu. A. Oliinyk, Theoretical basis of interaction of subjects in the innovation and investment sphere, Business Inform, Vol. 7, 18-24, 2015.

[5] A. A. Peresada, Investment Process Management, Libra, Kiev, 2002.

[6] T. V. Polozova. Formation of Innovation and Investment Mechanism to Ensure the Competitiveness of the Enterprise, Helvetica, Kherson, 2017.

[7] S. Agca, A. Mozumdar. The impact of capital market imperfections on investment-cash flow sensitivity, Journal of Banking and Finance, Vol. 32, No. 2, 207-216, 2008.

[8] A. Ascioglu, S. P. Hegde, J. B. McDermott. Information asymmetry and investment cash flow sensitivity, Journal of Banking and Finance, Vol. 32, 1036-1048, 2008.

[9] F.A. Al Sawalqa. Cash flows, capital structure and shareholder value: Empirical evidence from amman stock exchange, Accounting, Vol. 7, No. 3, 513-524, 2021

[10] P. Yu. Grechan, A. P. Grechan, O. G. Parfentieva. Stimulating innovative activity as a tool for ensuring strategic development of motor transport enterprises, Management Science Letters, Vol. 9, Iss. 10, 1655-1668, 2019.

[11] A. V. Kosenko. Innovation and investment component of the formation of the competitiveness of the national economy, Actual Problems of Public Administration, Vol. 1, 358-365, 2010.

[12] D. Ben Amara, H. Chen, M. Hafeez. Role of entrepreneurial opportunity identification factors in the eco-innovation of agribusiness, Business Strategy and Development, Vol. 3, No. 4, 435-448, 2020.

[13] I. R. Kriuchkova, S. V. Filippova. Innovative and Investment Activity of an Industrial Enterprise: Symbiosis of Economic Evaluation and Attraction of Sources of Financial and Alternative Resources, Publishing House PE "Bondarenko M.O.”, Odessa, 2015.

[14] S. V. Labunska. Approaches to the formation of the indicator of innovation capacity in the general system of economic security of the enterprise, Bulletin of Economics of Transport and Industry, Vol. 39, 55-59, 2012.

[15] L. O. Lihonenko. Methodology and tools for assessing the innovation of enterprises, Marketing and Innovation Management, Vol. 3, 105-117, 2015.

[16] O. V. Manoilenko, Ye. M. Strokov, M. O. Tkachenko. Management Innovative Processes: Formation of A Methodical Approach to Overcoming Barriers to Development. Competitiveness and Innovation: Problems of Science and Practice, VD "INZHEK", Kharkiv, 2013.

[17] T. O. Skrypko, B. M. Miziuk. Assessing the level of investment activity of small enterprises using investment security indicators, Bulletin of the National University "Lviv Polytechnic", Management and Entrepreneurship, No. 
$767,225-232,2013$.

[18] V. O. Yarmolenko, N. V. Polishchuk. Components of the performance of complex systems as objects of modeling, Bulletin of Cherkasy University, Economic Sciences, Vol. 33, No. 246, 86-93, 2012.

[19] T. Horodetska, K. Ivanchuk, L. Niekrasova, L. Semerun, K. Zaychenko. Food enterprises innovative activity organizing, Journal of Hygienic Engineering and Design, No. 27, 145$151,2019$.

[20] Ya. M. Beznesiuk. Problems and prospects for the development of the meat processing industry, Agrosvit, Vol. 12, 58-61, 2012.

[21] N. H. Hurzhii, Diagnosis of the market of meat processing products of Ukraine, Economics and Management of Agro-Industrial complex, Vol. 2, 46-52, 2014.

[22] O. O. Krasnorutskyi. Genesis and theoretical and methodological significance of the category "market distribution of products", Bulletin of Kharkiv National Technical University of Agriculture, Vol. 57, No. 2, 318 329, 2013.

[23] O. Kravchenko, V. Antoshchenkova, L. Batiuk, V. Lysenko. Price transmission among the participants of the livestock products agrofood chain in Ukraine, Research in World Economy, Vol. 11, No. 4, 72-80, 2020.

[24] Riveliño Ramón, Katherin Beltrán, Luis Verdezoto, Angel Remache , Favian Bayas-Morejón, "Preparation and Marketing of Granulated Panela in Family Businesses from Caluma (Ecuador)," Food Science and Technology, Vol. 8, No. 4, pp. 73 - 78, 2020. DOI: 10.13189/fst.2020.080401.

[25] N. A. Shelest. Monitoring of the state, problems and prospects of development of meat processing enterprises of Ukraine, Bulletin of Odessa National University, Economics, Vol. 19, No.1(2), 47-50, 2014.

[26] O. Yu. Sopotsko. Analysis of the market environment of enterprises in the production of sausages, Bulletin of the
Chernivtsi Trade and Economic Institute. Economic sciences, Vol. 4, 241-246, 2013.

[27] C. Z. Yuan, S. K. Ling. Long short-term memory model based agriculture commodity price prediction application, ACM International Conference Proceeding Series, 43-49, 2020.

[28] V. Gallego, P. Suárez-García, P. Angulo, D. Gómez-Ullate. Assessing the effect of advertising expenditures upon sales: A Bayesian structural time series model, Applied Stochastic Models in Business and Industry, Vol. 35, No. 3, 479-491, 2019.

[29] R. Ramón, K. Beltrán, L. Verdezoto, A. Remache, F. Bayas-Morejón. Preparation and marketing of granulated panela in family businesses from Caluma (Ecuador), Food Science and Technology, Vol. 8, No. 4, 73-78, 2020.

[30] O. M. Prokopenko. Export (import) of Meat and Edible Offal. In Statistical Collection "Agriculture of Ukraine", State Statistics Service of Ukraine, Kyiv, 2020.

[31] O. M. Prokopenko. Receipt of Farm Animals to Processing Enterprises. In Statistical Collection "Agriculture of Ukraine", State Statistics Service of Ukraine, Kyiv, 2020

[32] D. Dugassa Fufa, A. Abhram, A. Teshome, K. Teji, F. Abera, M. Tefera, M. Yeshitila, M. Mengistu, M. Gezahegn, T. Gure, T. Worku, T. Alemayehu, G. Egata. Hygienic practice of complementary food preparation and associated factors among mothers with children aged from 6 to 24 months in rural Kebeles of Harari region, Ethiopia, Food Science and Technology, Vol. 8, No. 2, 34-42, 2020. DOI: $10.13189 /$ fst.2020.080203.

[33] O. M. Prokopenko. Receipt of Farm Animals to Processing Enterprises. In Statistical Collection "Agriculture of Ukraine”, State Statistics Service of Ukraine, Kyiv, 2017.

[34] O. M. Prokopenko. Wholesale of Meat and Meat Products. In Statistical Collection "Wholesale and Retail Trade in Regions of the Ukraine", State Statistics Service of Ukraine, Kyiv, 2020. 